\title{
Financial Derivatives, Hedge Accounting and Tax Agoressiveness in Brazil
}

\section{Antonio Lopo Martinez, José Enrique Teixeira Reinoso, Rafael Moreira Antonio, Rogiene Santos}

\author{
University of Coimbra, Portugal \\ Fucape Business School, Brazil \\ University of Sao Paulo, Brazil \\ University of Sao Paulo, Brazil
}

This study investigated the relationship between the use of financial derivatives by non-financial corporations and tax aggressiveness in Brazil. In research on the American market, evidence was identified that non-financial entity users of financial derivatives were more tax aggressive. However, there is no reason to assume that this behavior is replicated in the Brazilian market, since tax legislation does not offer the same economic incentives, i.e., since it imposes limits on the tax deductibility of losses with these financial instruments, except in derivatives' well-documented and proven use as a hedge tool. To verify this point, companies were classified into users and non-users of first-generation financial derivatives, and associated this classification with tax aggression metrics. The study focus was 384 non-financial companies listed on the B3 in the period from 2005 to 2015. The results of regression analysis using a probit estimate have pointed, in a distinctly different way than the American reality, that the most tax aggressive companies tend to use fewer financial derivatives. Nevertheless, when the use of derivative instruments as a hedge was controlled, it was found that when a company adopts hedge accounting, it is more likely it will be more tax aggressive. The result is presumably explained by the Brazilian tax treatment that authorizes the deductibility of losses, regardless of earnings, when using the derivative as a hedge.

Keywords: Financial Derivatives, Tax Aggressiveness, Effective Tax Rate, Hedge accounting

\section{Derivados financieros, contabilidad de coberturas y agresividad fiscal en Brasil}

Este estudio investigó la relación entre el uso de derivados financieros por corporaciones no financieras y la agresividad fiscal en Brasil. En la investigación sobre el mercado estadounidense, se identificó evidencia de que los usuarios de derivados financieros de entidades no financieras eran más agresivos con los impuestos. Sin embargo, no hay razón para suponer que este comportamiento se replique en el mercado brasileño, ya que la legislación fiscal no ofrece los mismos incentivos económicos; es decir, impone límites a la deducibilidad fiscal de las pérdidas con estos instrumentos financieros, excepto en el uso bien documentado y probado de los derivados como herramienta de cobertura. Para verificar este punto, las empresas se clasificaron en usuarios y no usuarios de derivados financieros de primera generación, y se asoció esta clasificación con métricas de agresión fiscal. El estudio se centró en 384 empresas no financieras que cotizaron en el B3 en el período comprendido entre 2005 y 2015. Los resultados del análisis de regresión utilizando una estimación probit han señalado, de una manera claramente diferente a la realidad estadounidense, que las empresas más agresivas fiscalmente tienden a utilizar menos derivados financieros. Sin embargo, cuando se controlaba el uso de instrumentos derivados como cobertura, se encontró que, cuando una empresa adopta la contabilidad de coberturas, es más probable 
que sea más agresiva fiscalmente. El resultado se explica presumiblemente por el tratamiento fiscal brasileño que autoriza la deducibilidad de las pérdidas, independientemente de las ganancias, al utilizar el derivado como cobertura.

Palabras clave: derivados financieros, agresividad fiscal, tasa impositiva efectiva, contabilidad de cobertura

\section{Derivativos Financeiros, Contabilidade de Cobertura e Agressividade Tributária no Brasil}

Este estudo investigou a relação entre o uso de derivados financeiros por corporaçôes não financeiras e a agressividade tributária no Brasil. Na pesquisa sobre o mercado americano, identificou-se evidência de que os usuários de entidades não financeiras de derivados financeiros eram mais fiscais agressivos. No entanto, não há razão para supor que esse comportamento seja replicado no mercado brasileiro, uma vez que a legislação tributária não oferece os mesmos incentivos econômicos, ou seja, uma vez que impóe limites à dedutibilidade tributária das perdas com esses instrumentos financeiros, exceto no uso bem documentado e comprovado dos derivativos como uma ferramenta de hedge. Para verificar esse ponto, as empresas foram classificadas em usuários e não usuários de derivados financeiros de primeira geração, e associaram essa classificação com as métricas de agressão tributária. $\mathrm{O}$ foco do estudo foi 384 empresas não financeiras listadas na B3 no período de 2005 a 2015. Os resultados da análise de regressão usando uma estimativa probit apontaram, de forma distintamente diferente do que a realidade americana, que as empresas mais agressivas fiscais tendem a usar menos derivados financeiros. No entanto, quando o uso de instrumentos derivados como hedge foi controlado, verificou-se que, quando uma empresa adota a contabilidade de hedge, é mais provável que ele será mais fiscal agressivo. O resultado é, presumivelmente, explicado pelo tratamento tributário brasileiro que autoriza a dedutibilidade das perdas, independentemente dos ganhos, quando se utiliza a derivada como hedge.

Palavras-chave: derivativos financeiros, agressividade tributária, taxa efetiva de imposto, contabilidade de hedge

\section{Introduction}

The derivative market currently stands out for reaching a total amount in the trillions of dollars, which in itself corresponds to the class of the most relevant financial products in the world nowadays. Two important traits of these products are high leverage and the great liquidity of their segments (Santos \& Silva, 2017).

The Brazilian market is, at this moment, a breeding ground for using derivative instruments because they can decrease the risk of a certain transaction, smooth corporation operating results, as well as possibly increase the entity's own yield. On the other hand, the inappropriate use of derivatives can also cause immeasurable losses and even the the bankruptcy of the company (Galdi, Lopes, \& Lima, 2011).
Tax planning is a crucial instrument for expense reduction and decision-making of the entity managers (Hazan, 2004). That is, tax matters are considered by the managers in most of their routine strategic decisions (Klassen, Lisowsky \& Devan, 2016). Therefore, academic studies have struggled to clarify the derivative phenomenon in ligh of tax planning in the last two decades, whatever the reason why non-financial corporations use derivatives, whether due to hedge risk, to reduce non-tax costs or other agency costs, or as a sign of management quality, or, finally, to reduce tax volatility (Zeng, 2014).

Financial derivatives are assets, in which their respective roles depend on other more basic variants, being used as practice of avoidance and/or aggressive tax planning. They are securities whose future value is 
uncertain, unknown in the present. That is, there is no knowledge in the present of future results arising from these transactions (Mosquera \& Lopes, 2009). Thus, they are basically instruments of variable income. They are pacts which derive from other agreements, or which are related to the value of another asset. Based on that, the derivatives are usually used as hedges and/or speculation, with the use of the respective first generation financial products, such as: forwards, futures, swaps and options (Utumi, 2010). According to IFRS 9 (Financial Instruments), derivatives are a type of forward, regarded as buy and/or sell contracts of a specific amount of financial instrument, with delivery or liquidation on a specified future date. A futures contract is similar to a forward, but a priori there is a technical evolution, since they can be settled in cash.

The economic-financial objective of operations with derivatives is tied to the manager's actual intention, which does not constitute in itself a trait of the derivative, which can be used whether for protection (hedge) or for speculation. While used as a hedge, it seeks to protect the referenced asset/liability to variation risk in the price (Calijuri, 2009).

On the other hand, tax aggressiveness can be conceptualized as wide range of operations with the sole aim of reducing the total tax debt, as stated by Slemrod and Yitzhaki (2002). However, Chen, Dhaliwal and Trombley (2007) make a connection with tax planning when defining tax aggressiveness. To them, the main characteristic of tax aggressiveness is the reduction of income or the taxable income through the actions of tax planning. Furthermore, another definition for tax aggressiveness is taught by Lisowsky (2010), gathering a set of initiatives beyond just simple tax avoidance, differing from legitimate tax planning to investment in abusive tax havens (Martinez \& Ramalho, 2014).
In turn, the adoption of certain behaviors that seizes the disparity and technicality of tax standard, ends up generating a tax advantage, leading to a significant reduction of the amount to be paid by the taxpayer. This phenomenon is aggressive tax planning, which is autonomous from the simple tax planning, tax avoidance and/or tax abuse. Despite any implied immorality, it is legal, and therefore, admissible by Law (Caldas, 2015).

From these conceptually described premises, we seek to assess whether there is tax savings in the non-financial publicly held companies that are users of financial derivatives. We, then, come to the problem that encouraged the development of this study: Are the non-financial publicly held companies that perform tax avoidance planning in order to save in taxes, in fact helped by the use of financial derivatives? Thus, the main objective of this research will be to assess the effective relationship between the public company user of financial derivatives and tax aggressiveness and also to demonstrate that being a user of financial derivatives, the company tends to avoid more taxes than a non-user company.

Through the review of national and international literature related to this theme and econometric treatment of the data present in the accounting evincements of these non-financial corporations, it will be possible to relate the tax aggressiveness and the effective use of the financial derivatives by these companies (Martinez \& Martins, 2016). Based on the objectives explained so far, the hypothesis of this research can be formally stated as: Is there a relationship between the use of financial derivatives among the non-financial companies and tax aggressiveness in Brazil? It is crucial to highlight that in Donohoe (2015a) it was observed that, in the North American market, non-financial publicly held corporations which make use of financial 
derivatives are more aggressive from the point of view of taxation than those which are non-users of derivatives. Does this reality also take place in the emergent Brazilian market?

The main stimulus for setting this scientific research results from the gradual increase of the use of financial derivatives by non-financial companies in recent years in the regulated financial market, whether in world-wide or, specifically, in the Brazilian market. Moreover, the study is justified by the fact that it contributes to filling an academic gap in the texts regarding tax accounting in this country, namely: the results researched identify that the use of financial derivatives by companies listed on the B3 (Brazil, Exchange, Over-the-counter) may help the practice of tax avoidance planning.

In the rest of the article, first the theoretical benchmark will be presented followed by the research methodology, detailing the sample and models adopted. Next, the analysis of the results is presented. Finally, the research implications are appreciated and subsequent analysis to refine the research is proposed in the conclusion.

\section{Theoretical Benchmark}

In the modern world, relations with a company's environment are more dynamic, and many times it is not possible to wait for tomorrow's imponderable. Therefore, there are entities that adopt strategic defensive postures, while others are more audacious. Thus, it is clear that a purely defensive strategy avoiding risks and uncertainties, limits the success and, in turn, the level of tax aggressiveness in tax planning (Martinez, 2017). In this complex environment, the proper tax planning along with a precise level of tax aggressiveness has been having a great impact on the daily course of business for many entities, which provides several applications at the strategic level for business organizations (Graham, Hanlon, Shevlin, \& Shroff, 2014).

A derivative is an economic concept that has become, due to its relevance to society, an accounting and even legal concept. And because of the complexity of the transactions in the world market, it is required that the administrator honors and safeguards items, even those which are not shown in the balance sheet but which are part of the company assets, such as cash flow and future revenues, and this is why so much prestige been given to the study of financial derivatives (Bifano, 2009).

In general, what is seen is the use of derivatives for the purpose of helping companies manage financial risks that threaten their revenues, product costs and miscellaneous expenditures. However, financial derivatives can also be used in tax planning. A recent study concluded that corporations jointly avoided $\$ 7.3$ million euros in taxes during three years since the beginning of the use of derivatives (Donohoe, 2015a).

\subsection{Financial Derivative Taxation in Brazil}

Taxes on derivatives in Brazil are Income Tax, Social Contribution and the Tax on Financial Operations (IOF). The IOF appears when the derivative is issued, transmitted, paid and/or redeemed, whenever it is negotiated, even without net gain; it will also be retained by the Financial Institution and/or Brokerage firms. There will be the incidence of Income Tax, however, in case of effective gain in the operation with the derivative, and, as a general rule, it is a $15 \%$ fixed rate. Nevertheless, regarding the swap, the rate is similar to the one used in fixed income operations, which vary from $15 \%$ to $22.5 \%$, varying according to the periodicity of the assets in the portfolio (Articles 790 
and 854 of the Decree Law \# 9.580/2018 - Income Tax Regulations, as well as Articles 46, 50, 58 to 63 of the Normative Ruling \# 1585/2015).

Moreover, in corporations subject to the systematic review of Real Income, the gains resulting from the derivatives are accounted as financial revenue, forming unwittingly company tax profit. In general, in Brazil, there is no deduction of the loss resulting from the use of derivatives. Nonetheless, there is an exception regarding hedges, since in the negotiations with derivatives for risk coverage, fulfilling the requirements of the National Treasury, the deduction of eventual loss with the use of derivatives will be allowed.

That is, in case it is not proved and/or is not effectively a hedge, the operation will be automatically considered non-deductible for the purpose of Income Tax (Article 466 of the Decree Law \# 9.580/2018 as well as Articles 51, 52, 56 and 71 of the Normative Ruling \# 1585/2015). It is also worth highlighting that the Treasury has continually issued Notices of Violation when it has verified that the taxpayer has alleged a derivative to be hedge with a speculative purpose, and charged, therefore, $34 \%$ over the alleged loss, added to the default interest, as well as a $75 \%$ to $150 \%$ variable fine (calculated on the tax eventually due).

The tax complexity involving the financial derivatives in Brazil is notorious, and that is the one reason why it differs from the American reality envisaged by Donohoe (2015a) when dealing with the effects in tax planning of the use of financial derivatives. It is recognized that even the tax legality in Brazil brings insecurity to the administrators, who besides worrying about the legality aspects, must also study the implicit tax, the cost involved in operations and the involved parties for an efficient taxation (Calijuri, 2009).
Likewise, since the management of results is a reality of any business strategy, the use of derivatives tends to be incentivized by the reduction of the tax burden, which is the fundamental reason for aggressive tax planning. Tax planning thus ultimately seeks to maximize company value through the increase of its performance (Rezende \& Nakao, 2012).

Nevertheless, when the companies make decisions that affect the accounting and tax results, they must take into account all the involved parties, all the incident taxes, and, finally, all the costs involved (Shackelford $\&$ Shevlin, 2001). Thus, it is essential that the administrator have mastery of the explicit and implicit tax of each decision making, in order to optimize, with strategic efficiency, the result allocation.

Based on this, financial derivative products can be seen as useful for the practice of tax avoidance planning, since they can soften the tax yield, reproduce nearly all economic positions with no blur of the economic substance and/or essence, and, finally, increase the ambiguity of tax reports due to its interpretational complexity (Donohoe, 2015b). From this premise, the practice of the use of financial derivatives can be empirical evidence of tax planning, since the derivative is a financial (speculative) and/or protection (safeguard) contract resulting from its value based on the value of the underlying asset (Stulz, 2004).

The use of derivatives by publicly held companies are motivated by their ability to isolate earnings and cash flow from risk; thus, unfavorable changes of interest rates, exchange rates and prices of commodities do not impact the company's results (Bartram, Brown \& Fehle, 2009).

The protection takes place since the operation with derivatives is structured in such a way that the price 
variation of the derivative goes in the opposite direction of the price it is protecting. For instance, suppose a company has debts in dollars and intends to protect its liabilities from a possible dollar appreciation, which would increase the liquidity amount of the debts in domestic currency. For this purpose, it can perform a swap operation in which it changes the variation in Brazilian reais into the variation of the Interbank Deposit Rate - CDI (Calijuri, 2009).

If the currency decreases in value and, in turn, depreciates against the dollar, the company debt in dollars would increase in reais. Therefore, the Bank which negotiated the swap with the company must pay the difference between the amount of debt to be paid and the effective amount of the debt converted into Reais when the operation was contracted, updated by the CDI. It is protection against the appreciation on foreign currency.

While when a derivative is used for protection or hedge, operations which reduce the exposure to risk of the implementing party of this operation are carried out, the opposite occurs when the financial derivatives are used for speculation. In this scenario, the goal is to bet on the actual price or rate variation. In contrast to risk hedgers, the speculators accept taking risks and being exposed to undesirable price variations.

Financial derivatives are classified, in general, in four categories: option, forward, future, and swap (Ryan, 2007). Although the use of options, futures, forwards and swaps are common in practice, these derivative products are also commonly combined with other instruments (or with a derivative of another type) to create more specialized instruments. For instance, combining an option with a swap, you create an option to enter in a swap (a "waption"), while the use of "options with future contract" offers the holder of a position a determined particularity in a contract of futures.

In this context, the use of derivatives by non-financial companies makes tax avoidance planning easier, as well as it interacts with practices of aggressive tax. Nowadays, the trend of tax planning based on the use of derivatives keeps on increasing and it does not show any sign it will fade away (Raskolnikov, 2011). A recent study on the stock market in Canada demonstrated empirically that the use of financial derivatives tends to be an efficient strategy of tax planning, via "tax-timing options". That is, the study considered brought empirical evidence that when the companies use derivatives, they realize accounting losses or do not realize gains independently of the relationship with the increase of actual taxation (Zeng, 2014). Also, it was shown that in the Canadian market, the realization of losses by the entities and/or the absence of gains by the use of financial derivatives are positively related to the variation of the stock market. This pioneering study clearly concludes the motivational relationship of the use of derivatives for the effective practice of tax planning (Zeng, 2014).

The initiatives of tax planning in the overall context of business can contribute to the reduction of tax obligations. Nevertheless, as a rule, most businesses just worry about the reduction of explicit taxes. In turn, an instrument's aggressiveness level measures the purpose of the passive subject in reducing its tax burden, not even paying attention to tax legality (Martinez, 2017). Thus, increasing the tax aggressiveness level, i.e., the tax risk of the corporations, can unwittingly cause an enhance risk of notices of violation issued by the treasury official. Tax risk and tax aggressiveness go together; despite the conceptual difference they are positively related to the same ideal (Martinez \& Silva, 2018). 


\subsection{Tax Planning and Financial Derivatives}

Furthermore, Figure 1, taken and adapted from Lietz (2013), shows the conceptual confusion that turns around tax planning, illustrating it as a broad concept that corresponds to a set of strategies of explicit and implicit tax reduction. According to him, Aggressive Tax Planning would be just the effective reduction of explicit tax, and only Tax Evasion would be the clearly illegal planning, resulting from failure to pay the tax actually owed.

Figure 1 clearly presents that the aggressive tax planning, as a reduction of explicit tax, persists as a legal concept which has in its core, an uncertainty zone inherent to the theme itself since the law itself does not bring objective elements to characterize plans as legal and/or illegal. Moreover, in Figure 1, it is clearly shown that the company that has an effective tax rate (ETR) proxy with a high coefficient will have a booktaxes differences (BTD) proxy with a low coefficient, and it will, consequently, not be considered tax aggressive. On the other hand, when the corporation has an ETR variable with a lower coefficient and/or with a higher BTD, it is characterized as a tax-aggressive corporation.

Contemporary tax planning has been studied since Scholes and Wolfson (1992), who noted that effective tax planning requires, from the administrator, the acknowledgement that taxes are equivalent to just one among the many costs of the business. In this context, the analysis of tax planning just under the lawfulness or tax specificity perspective is no longer recommended, because tax management currently requires a multidisciplinary perspective, in which three dimen-

Figure 1. Tax Planning Concepts

TAX PLANNING

"All the parties, all the taxes, all the costs"

Explicit and Implicit Tax

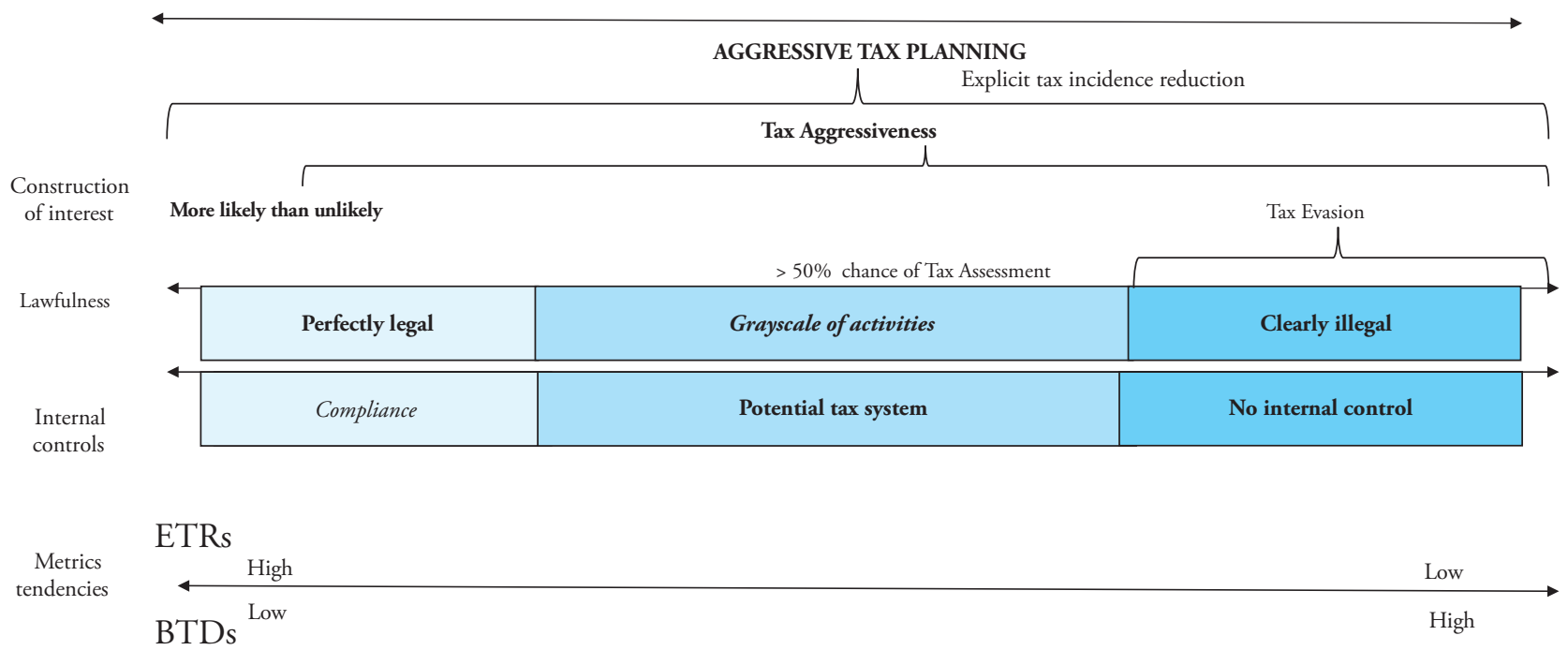

Source: Adapted from Lietz (2013) and Martinez (2017). 
sions must always be assessed: "all the parties, all the taxes and all the costs" (Scholes \& Wolfson,1992). Otherwise, the planning would just minimize an alleged effective tax burden, not even maximizing the company value, which is the inexorable objective of this multidisciplinary perspective (Calijuri, 2009).

The use of financial derivatives by publicly held companies deserves attention due to the reasons that lead to their use and how this use reflects the tax aggressiveness of these entities. That is, a key resource is the ability to reduce (hedge) to risk exposure, decreasing the volatility of taxable yield (Keyes, 2008). In other words, with the softening of taxable yield, the efficient coverage through hedge can reduce the amount expected from the taxes, and consequently increase the company value (Donohoe, 2015a). In eliminating the volatility of taxable yield, the company reduces its tax responsibility as long as the hedge is efficient (Yanchisin \& Ricks, 2006). Thus, the protection of tax debt is another fundamental reason for good taxable yield since it can result in less taxation. As the companies increase their indebtedness capacity, the possibility of tax deductions increases and so does the company value (Donohoe, 2015a).

Speculation operations hope to obtain gains from greater exposure to risks. The speculators, who study and project trends on endless variables, are experts in market. They invest on certain derivatives because they believe in the materialization of these trends. Therefore, these speculators, when taking risks, are subject to not only high gains, but also great losses. The speculators have the role of bringing greater liquidity margins to the market since they perform innumerable numbers of operations (Galdi et al., 2011).

Moreover, the use of financial derivatives has different tax treatments, which is an incentive to financially engineer new financial derivatives outside the ones contemplated by the current tax rules. Thus, similar economic positions are taxed differently, according to the versatility inherent to the financial derivatives themselves. Therefore, financial engineering seeks less onerous solutions, or one with better tax results to the company (Donohoe, 2015a). New derivatives are uneventfully created to satisfy a variety of needs and financial aims, while the traditional derivatives are explored and readjusted as new financial products (Keyes, 2008). Thus, it is obvious that the rules which standardize the derivatives become fragile and are enough fuel to foment habits of avoidance planning.

Not only that, it is possible, according to the company administrator's convenience and opportunity, to speed the tax deductions and postpone the taxable yield for future periods in order to ease the management of results. Thus, aggressive use of derivatives will contribute to the reduction of tax payments in the current period, for instance. Even financial professionals, analysts, accountants and lawyers interpret differently the risks, rewards and gains resulting from the use of financial derivatives. Consequently, companies, in face of such complexity of financial derivatives, make use of this advantage in tax avoidance plannings, via the several strategies which enable them to be "below the enemy's radar." Whatever the treasury official's effort, they hardly identify the "actual" tax economy intended by the taxpayer (Donohoe, 2015a).

Therefore, the seemingly low probability of detection by the tax official is a strong incentive for companies to perform tax planning using derivatives. Although tax management of the derivatives is very onerous, the professional expertise is available in these companies, which makes the implementation, and the sophistication of the intended tax planning needed relatively easy. In short, financial derivatives are attractive to 
aggressive companies since they can soften the taxable yield, reproduce practically any economic position intended without jeopardizing its economic essence, as well as to enhance the ambiguity of tax reports, resulting in the low probability of a tax official intervention.

\subsection{Hedge Accounting}

The hedge operation, especially hedge accounting, requires the corporation to prove it really is a coverage operation, since its booking as hedge accounting is not compulsory (Moreira, 2004). Nonetheless, when all the necessary requirements are fulfilled, it will become a corporation's right, which will then provide inherent accounting and tax benefits to the entity.

In its turn, the idea is that a certain portfolio hedge is restricted to clearly distinguishable risks, and that in fact they can be mitigated with the operation. There are three categories of such hedges: i) fair value hedge; ii) cash flow hedge; and iii) hedge of instruments abroad (Galdi et al., 2011). Since the key aim of this research is the use of financial derivatives related to tax aggressiveness, the hedge issue deserves attention since the use of derivatives for safeguarding the corporation from countless risks has close relationship to tax planning.

When a swap operation is carried out, one variable risk is exchanged for a different one. In fact, there is the effective transference of the risk initially exposed to a new risk. For instance, when an entity owing in dollars carries out a swap, in which it will receive an exchange rate and pay the rate pegged to CDI, it is changing risks.

When the corporation changes risks, it protects itself from the risk it was initially exposed to, therefore, the use of derivatives with a hedge aim is a protection operation. In fact, it is an effective protection in rela- tion to the initial exposure. It is not speculative; it is clearly related to the purpose activity of the corporation. Moreover, the only possible gain is the reduction of its funding cost (Galdi et al., 2011). Thus, hedge accounting is a special procedure, in which rules of the jurisdiction is applied since the result of the hedge tool must be accounted at the same time as the result of hedge object. That is, the entity is free to not use hedge accounting, but once it is adopted, it is obliged to follow what is laid down in an accounting standard (Galdi et al., 2011).

It is important to highlight that this conceptual discussion has direct relevance to the tax lawfulness, therefore the losses resulting from operations with financial derivatives can only have their sum deducted at tax profit ascertainment when it refers specifically to operations considered hedge accounting. That is, tax law has assigned the losses resulting from hedge operations similar status to those given to the operating expenses. Their deductibility results from the positive connection that these results have with the operational activity of the corporation (Mosquera \& Lopes, 2009).

It is worth highlighting that one can not imagine a more operational element for a company than its funding. Third-party capital is essential for the business survival, that is the reason why the idea of reducing funding costs of their obligations to third parties is umbilically connected to operating activities (Mosquera \& Lopes, 2009). Regarding Brazil, the high cost of third-party capital may hinder the future of the business. Thus, the activities related to the reduction of contracted capital cost are considered operational and necessary for the management. They are financial expenses, therefore operational (Mosquera \& Lopes, 2009).

Contabilidad y Negocios (15) 29, 2020 / ISSN 1992-1896 
All in all, the hedge must be connected to the company operational routine, since the law usually ties the deductibility of the operations with derivatives to its purpose, which is as a hedge. Following this line of reasoning, only operations with such specificity will have the loss deducted from the taxable profit. It is also necessary to clarify that, tax law attributes losses resulting from hedge operation regimen similarity to that provided by the legislation to the corporation operational expenses. Thus, negative results with hedge-purpose derivatives must be calculated from the taxable profit, as the corporation's operational expenses were.

\section{Methodology}

The research design was quantitative, descriptive, and used a probit regression estimation was used on a sample comprising corporate entities to evaluate the use of derivatives. The model was adapted from Bartram et al. (2009), who studied international empirical evidence of the use of financial derivatives through probit estimation. The probit was adopted as the estimation econometric model due to the possibility of probabilistic analysis between the binary variables.

The sample basis of the future research was limited to non-financial publicly held companies listed at the Stock Exchange (B3), which, in Brazil, is now called the Stock and Counter markets, during the period from 2005 to 2015 . This time period was chosen in order to seek ten years of effective sample and, in turn, control the volatility of the ETR proxy over the years. The year 2010 is justified because it is after the RTT (Transitional Tax Regime), which triggered off invariable tax changes in the existing legal framework. This selection is delimited at 2015 by the range of compiled data obtained, as well as for being the year of the introduction of the IFRS international accounting standards, introduced through Law 12,973/2014.
The need to establish proxies was seen and they were used to measure the level of tax aggressiveness related to tax planning, whether it is the Total ETR or the Current ETR. Their level of relevance and the treatment methods will be explained below, aiming to subsidize the decision making process. From these indicators, it is possible to define the goals, carry out the control and assessment of the results (Ferreira, Martinez, Costa, \& Passamani, 2012).

Likewise, there are, in international literature, more widespread ways to identify the tax planning of companies; among them, the Effective Tax Rates - ETR - stands out, according to the chart below. The ETR calculation, however, is often used to measure the level of tax management of the companies, therefore it shows objectively the effective tax rate on the profit.

As shown in Table 1 below, this empirical study adopts the ETR index as the calculation that divides tax estimate by a measure before the taxes on the profit, since it measures the relationship of Income Tax and profit before the calculation of IRPJ (corporate income tax), in order to reach the aggressive tax planning of the entity (Hanlon \& Heitzman, 2010).

Table 1. Tax Aggressiveness Measures

\begin{tabular}{|l|l|l|}
\hline \multicolumn{1}{|c|}{ Measures } & \multicolumn{1}{|c|}{ Calculation } & \multicolumn{1}{c|}{ Description } \\
\hline $\begin{array}{l}\text { ETR - Effective } \\
\text { Tax Rate }\end{array}$ & $\begin{array}{l}\text { Total Expense } \\
\text { with tax / Profit } \\
\text { before tax }\end{array}$ & $\begin{array}{l}\text { It reflects the effective rate } \\
\text { of taxes paid, in relation to } \\
\text { profit before tax. }\end{array}$ \\
\hline $\begin{array}{l}\text { BTD - Book } \\
\text { Tax Difference }\end{array}$ & $\begin{array}{l}\text { Difference } \\
\text { between Book } \\
\text { profit and } \\
\text { taxable profit }\end{array}$ & $\begin{array}{l}\text { BTD is a robust proxy; } \\
\text { the greater it is, the weaker } \\
\text { the relationship between } \\
\text { taxable and book profit. }\end{array}$ \\
\hline
\end{tabular}

Source: Martinez and Ramalho (2014).

Moreover, the BTD proxy, which is the difference between corporation accounting profit and taxable profit, should be used in the analysis as well. It is seen that the corporations with high BTD have lower ETR, 
and the higher the BTD, the weaker the relationship between taxable profit and the accounting result (Hanlon \& Heitzman, 2010). Finally, high BTD with positive coefficient sign will directly correspond to the aggressiveness planning chosen by the entity administrator (Mills, Erickson, \& Maydew, 1988).

From these premises considered, the ETR metrics, i.e. both the Total ETR and the Current ETR, mentioned in the theoretical framework as well as being the proxies adopted by the contemporary accounting literature, in addition to the BTD proxy, which also has robust contribution in result and tax management, will be used to establish the most aggressive companies regarding taxes.

\section{Table 2. Interpretation of Tax Aggressiveness Metrics}

\begin{tabular}{|l|l|l|}
\hline METRICS & \multicolumn{1}{|c|}{ CALCULATION } & INTERPRETATION \\
\hline BTD & $\begin{array}{l}\text { LAIR }-\{(\text { IRPJ Expense }+ \\
\text { CSLL }) / 0.34)\}\end{array}$ & $\begin{array}{l}\text { The greater the BTD, } \\
\text { the more aggressive } \\
\text { the company is. }\end{array}$ \\
\hline $\begin{array}{l}\text { ETR } \\
\text { Total }\end{array}$ & $\begin{array}{l}\text { (Total IRPJ Expense }+ \\
\text { CSLL) / LAIR }\end{array}$ & $\begin{array}{l}\text { The greater the ETR, } \\
\text { the less aggressive the } \\
\text { company will be }\end{array}$ \\
\hline $\begin{array}{l}\text { ETR } \\
\text { Corrente }\end{array}$ & $\begin{array}{l}\text { (Current IRPJ Expense }+ \\
\text { CSLL) / LAIR }\end{array}$ & $\begin{array}{l}\text { The greater the ETR, } \\
\text { the less aggressive the } \\
\text { company is. }\end{array}$ \\
\hline
\end{tabular}

After collecting the sample, each company group was classified by their respective ETR values, with the purposes of relating these proxies later on to aggressive and/or moderate management levels, describing the phenomenon of the national capital market, and demonstrating aggressiveness determinants and finally identify market effects.

Finally, regarding the data collection, the secondary Economática software database will be used. For this reason, there must be a wide view of the information elaborated, excluding companies without accounting disclosures, as well as those from the financial sector, since they have a special 15\% CSLL rate, different from the $9 \%$ for most other companies, besides their sector-specific accounting procedures.

\section{Statistical Models}

Aiming to associate the tax aggressiveness proxies with the use of financial derivatives by non-financial companies, the multiple regression model with two binary dummy variables, presented in Equations (1) and (2), was developed:

$$
\begin{gathered}
\operatorname{TaxAgg}_{i, t}=\beta_{0}+\beta_{1} U_{S E R_{i, t}}+\beta_{2} \operatorname{SIZE}_{i, t}+\beta_{3} L E V_{i, t} \\
+\beta_{4} \Delta L E V_{i, t}+\beta_{5} \operatorname{ROA}_{i, t}+\beta_{6 .} \Delta R O A_{i, t} \\
+\beta_{7 .} B T M_{i, t}+\beta_{8} D E P_{i, t}+\varepsilon_{i, t} \quad \text { Eq. }
\end{gathered}
$$

$$
\begin{array}{r}
\operatorname{TaxAgg}_{i, t}=\beta_{0}+\beta_{1} H E D G E_{i, t}+\beta_{2} S_{Z Z E_{i, t}}+\beta_{3} L E V_{i, t} \\
+\beta_{4} \Delta L E V_{i, t}+\beta_{5} \boldsymbol{R O A}_{i, t}+\beta_{6} \Delta R O A_{i, t} \\
+\beta_{7 .} B T M_{i, t}+\beta_{8} D E P_{i, t}+\varepsilon_{i, t} \quad \text { Eq. (2) }
\end{array}
$$

Equation (1) is the main regression of this paper hypothesis. Equation (2), on the other hand, is an additional model to the proposed hypothesis, in which a HEDGE variable was added to the independent variables of Equation (1) main model. The above parameters are defined as:

$\boldsymbol{T a x A g g _ { i , t }}=$ Dependent variable of tax aggressiveness measured by the following metrics: Total ETR, Current ETR and BTD, of company $i$ in year $t$;

$\boldsymbol{\beta} 0=$ Multiple regression intercept;

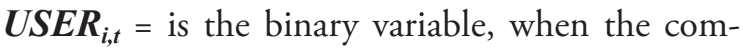
pany $i$ in the year $t$ is user or non-user of financial derivative, which takes on value equal to " 1,00 " if the company is a user, and " 0.00 " when it is not a user; 
$\boldsymbol{H e d g}_{\boldsymbol{i t}}=$ is the binary variable when the company $\mathrm{i}$ in the year $\mathrm{t}$ uses, or not, Hedge Accounting, taking on value equal to " 1,00 " if the company uses Hedge Accounting, and " 0.00 ” when it does not;

$\boldsymbol{S I Z E _ { i , t }}=$ Control variable for the size of the company $\mathrm{i}$ in the year $\mathrm{t}$, measured by $\ln$ of the total assets of the previous year;

$\boldsymbol{L} \boldsymbol{E} \boldsymbol{V}_{i, t}=$ Control variable for leverage of the company $\mathrm{i}$ in the year $\mathrm{t}$, measured by long-term debts, divided by the total assets of the previous year;

$\Delta \boldsymbol{L} \boldsymbol{E} \boldsymbol{V}_{i, t}=$ Control variable for leverage variation, measured by the leverage in $\mathrm{t}$ minus the leverage $\mathrm{t}-1$, divided by the total assets of the previous year;

$\boldsymbol{R} \boldsymbol{O} A_{i, t}=$ Control variable for return on assets of company $\mathrm{i}$ in the year $\mathrm{t}$, measured by the profit before taxes divided by the total assets of the previous year;

$\triangle \boldsymbol{R O} \boldsymbol{A}_{i, t}=$ Control variable for the variation in $\mathrm{ROA}$, measured by the ROA in $\mathrm{t}$ minus ROA in $\mathrm{t}-1$, divided by the total assets of the previous year;

$\boldsymbol{B T M}=$ Book to Market Ratio control variable, measured by the Net Equity by the company market value;

$\boldsymbol{D E P}_{i, t}=$ Control variable of the Depreciation of the company $i$ in the year $t$;

$\varepsilon \mathbf{i t}=$ Error term.

\section{Results}

Initially, a descriptive analysis of each variable was carried out to point potential impediment resulting from an alleged linearity.

Table 3 shows the descriptive numerical measure, through the sample of this research target variables, resulting from the respective 4.214 observations, of the 384 sampled companies listed in B3, according to the data collections of their respective classes of common shares in the last ten years (2005 to 2015).

It is interesting to observe that $37 \%$ of the entities in the sample analyzed were effective users of financial derivatives, as well as while users of financial derivatives, the average of the metrics of the entities studied are very close to $34 \%$, which corresponds to the sum IRPJ nominal rate + CSLL charged (Brazilian corporate income taxes), in general, from the non-financial companies.

Regarding the medians, the values are lower than the averages, indicating that there are significant number of companies with ETR values below the 34\% statutory rate, as also indicated by the high standard deviations in the Total ETR, Current ETR and BTD proxies.

Table 4 presents the correlation between the control and dependent variables adopted in the econometric model, avoiding, as much as possible, estimation bias

Table 3. Descriptive Statistics

\begin{tabular}{|l|c|c|c|c|c|c|}
\hline & Average & Std.dev. & Median & 5\% Perc & 95\% Perc & C.V \\
\hline User & 0,3740 & 0,4840 & 0,0000 & 0,0000 & 1,0000 & 1,2941 \\
ETR Total & $\mathbf{0 , 3 1 9 2}$ & 1,5484 & 0,2197 & 0,0000 & 0,6122 & 4,8507 \\
BTD & $\mathbf{0 , 1 2 1 5}$ & 1,3689 & 0,1284 & $-0,2757$ & 0,6422 & 2,5142 \\
Current ETR & $\mathbf{0 , 3 2 8 8}$ & 1,6585 & 0,1940 & 0,0000 & 0,6925 & 5,0433 \\
\hline
\end{tabular}


and collinearity between these variables. In fact, in general, it was not identified. Nevertheless, it was seen that just the BTD variable, when correlated to independent and VarRoa control variables, presented 99\% of correlation. Therefore, the eventual correlation of the BTD with the VarRoa must be observed, and, eventually, was excluded in the subsequent regression.

The existence of negative sign between the BTD tax aggressive metrics and the other proposed metrics is clear, in accord with Hanlon and Heitzman (2010), who stated that the companies with great BTD would have lower ETR proxies. In turn, some tests were carried out in the database collected, and considering the OLSs of the variables, statistical significances which justified the model and/or proved the hypothesis pro- posed in this short paper were not found, and that is why another analysis estimate will be proposed for the regression.

In Table 5, the averages, medians and variation coefficients between the users of financial derivatives are presented, separating the users and non-users of financial derivatives into each one of the three aggressiveness metrics adopted. Importantly, different from what was presented in the international literature, non-users of financial derivatives have lower values than the financial derivative users, either regarding the Total ETR, Current ETR and/or BTD, reasons why they would indicate a trend that the most tax aggressive entities would be those who use financial derivatives in their corporate routine.

Table 4. Correlation Matrix between the Variables

\begin{tabular}{|l|c|c|c|c|c|c|c|c|c|c|}
\hline & DEPREC & BTM & VARROA & ROA & VARLEV & LEV & SIZE & BTD & Current ETR & TotalETR \\
\hline DEPREC & 1,0000 & & & & & & & & & \\
BTN & $-0,1687$ & 1,0000 & & & & & & & & \\
VARROA & $-0,0389$ & $-0,195$ & 1,0000 & & & & & & & \\
ROA & $-0,0389$ & $-0,195$ & 1,0000 & 1,000 & & & & & & \\
VARLEV & $-0,0039$ & 0,005 & 0,0114 & 0,0114 & 1,0000 & & & & & \\
LEV & $-0,0039$ & 0,005 & 0,0114 & 0,0114 & 1,0000 & 1,000 & & & & \\
SIZE & 0,1053 & 0,035 & $-0,2624$ & $-0,262$ & 0,0003 & 0,0003 & 1,000 & & & \\
BTD & 0,0548 & $-0,197$ & 0,9937 & 0,9937 & 0,0110 & 0,0110 & $-0,25$ & 1,000 & & \\
curETR & 0,1750 & 0,016 & $-0,1376$ & $-0,138$ & $-0,007$ & $-0,007$ & 0,04 & $-0,17$ & 1,0000 & \\
totETR & $-0,0011$ & 0,057 & $-0,0902$ & $-0,09$ & $-0,002$ & -0.002 & $-0,01$ & $-0,08$ & 0,3153 & 1,0000 \\
\hline
\end{tabular}

Table 5. Averages and Medians

\begin{tabular}{|l|c|c|c|c|c|c|}
\hline & AVERAGE & STD.DEV & MEDIAN & 5\% PERC & 95\% PERC & C.V \\
\hline NonUser Total ETR & 0,1228 & 3,4575 & 0,2373 & $-0,2841$ & 0,6054 & 28,1490 \\
User Total ETR & 0,2434 & 2,3978 & 0,2524 & $-0,4022$ & 0,6126 & 9,8487 \\
\hline NonUser Current ETR & 0,1069 & 3,5056 & 0,1921 & $-0,2455$ & 0,6018 & 32,7790 \\
User CurrentETR & 0,2366 & 2,1495 & 0,1254 & $-0,4249$ & 0,7900 & 9,0828 \\
\hline NonUser BTD & 0,1115 & 0,3121 & 0,1350 & $-0,2761$ & 0,4614 & 2,7969 \\
User BTD & 0,1379 & 0,1932 & 0,1254 & $-0,1506$ & 0,4580 & 1,4006 \\
\hline
\end{tabular}


In the analysis of the 647 observations which are derivative users, compared to 1.042 non-user observations, through the Total ETR, the model has not resulted in statistical significance ( $\mathrm{p}$-value $=0.1818$ ), circumstance that deserves and requires a further study due to the peculiarities of the Brazilian economic reality.

Moreover, between the derivative users, based on the Current ETR proxy (618 observations) and those which are non-users (1.011observations), no statistical significance was obtained either ( $p$-value $=0,4556$ ), since the null hypothesis is the medians are equal. Consequently, the test between the user and non-user companies was carried out, based on the BTD robust metrics, and no statistical significance was observed $(\mathrm{p}$-value $=0,9333)$.

Based on this study between the three dependent variables mentioned, because of the low level of reliability evinced, the search for another study estimate was required since the traditional ordinary least square (OLS) method did not bring statistical relevance to estimate the regression model proposed. Such result is logit therefore, the OLS is not enough to justify tax planning because there are invariable ways the planning can be carried out, whether with premium, exploration profit, among others. Therefore, the OLS tends to take into consideration only the use of financial derivatives as instruments to obtain tax planning, which does not correspond to the world market practice, especially in Brazil.

Thus, the probit method was adopted for the regression estimation, which does not take into account the financial instrument as the only alternative to perform, or not, aggressive tax planning. This probit estimation was significant for this study of the statistical model proposed, considering the variation of the sample size, as well as taking into account the real probability of the effective use of financial derivative to the practice of tax planning.

Furthermore, a proper statistical model based on qualitative choices is through the probabilities, consequently, the probit estimation was used. Probit, in face of a dependent or binary explained variable (dummy), performs functions of specific distribution, the logic and normal ones, for the calculation of probabilities (Freitas, 2013).

It is important to clarify that adopting the probit model has not qualitatively altered the statistical result, but, if another estimate model was adopted, logit, for instance, the result would be the same. Nonetheless, the logit model, despite the simplicity of math calculation for ungrouped data, would require to draw on non-linear estimation procedure, based on the maximum likelihood estimation method, which is the reason why the probit estimation model was chosen.

Therefore, the companies collected were separated in order to use the regression model with probit estimation, considering that the companies with greater tax aggressiveness would be those that presented the lowest ETR values in the sample. The most aggressive ones were in the 1 st. quartile and were assigned a " 1.00 " dummy) and, consequently, rest of the companies not in the 1 st. quartile were assigned the " 0.00 " dummy. That is, the most aggressive companies were compared to the other $75 \%$ of the companies present in the sample.

In the analysis, only the Current ETR and the Total ETR had significance in the regression, demonstrating that the users of financial derivatives unwittingly are not those most tax aggressive entities. The Current ETR variable, as dependent variable, in the 1.350 observations presented statistical relevance to the model ( $\mathrm{p}$ value $=0,0008)$, despite the squared $\mathrm{R}(0,2145)$ and the adjusted R $(0,1991)$ having no significance. Finally, 
Table 6. The 25\% Most Aggressive (vs) the Other 75\% Least Aggressive Companies

\begin{tabular}{|c|c|c|c|c|c|c|}
\hline & \multicolumn{2}{|c|}{ CURRENT ETR } & \multicolumn{2}{|c|}{ TOTAL ETR } & \multicolumn{2}{|c|}{ BTD } \\
\hline PROBIT & Coefficient & P-value & Coefficient & P-value & Coefficient & P-value \\
\hline CONST & $-0,5349$ & $0,0021^{* * *}$ & $-0,8633$ & $0,0001^{* * *}$ & $-5,7010$ & $1,32 \mathrm{e}-027^{* * *}$ \\
\hline USER & $-0,4446$ & $0,0002^{* * *}$ & $-0,3996$ & $0,0043^{* * *}$ & 0,1587 & 0,3163 \\
\hline VARLEV & $7,80727 \mathrm{e}-05$ & 0,4309 & $-3,52492 \mathrm{e}-05$ & 0,6050 & $2,65218 \mathrm{e}-06$ & 0,9963 \\
\hline VARROA & $-0,0839$ & $4,07 \mathrm{e}-012^{* * *}$ & $-0,0478$ & $2,62 \mathrm{e}-07^{* * *}$ & 0,6597 & $3,51 \mathrm{e}-035^{* * *}$ \\
\hline DUMMYNOL & $-0,1786$ & 0,3062 & $-0,1743$ & 0,4081 & 0,152 & 0,5227 \\
\hline DEPREC & $-7,5081$ & $0,0057^{* * *}$ & $-12,5305$ & $0,0005^{* * *}$ & $-7,9652$ & $0,0027^{* * *}$ \\
\hline BTM & 0,0430 & $0,0261^{* *}$ & $-0,0305$ & $0,0901^{*}$ & $-0,0783$ & 0,7107 \\
\hline
\end{tabular}

Note: $10 \%$ Significance level $(*), 5 \%$ Significance level $\left({ }^{* *}\right)$ and $1 \%$ Significance level $\left({ }^{* *}\right)$. The tests which were not significant had p-value higher than 0,1 (N.S).

the Total ETR, in the 1.324 observations also had statistical relevance to the model ( $\mathrm{p}$ value $=0,10)$, with squared R (0,072) and adjusted R (0,051), with the independent variables with significance as shown in Table 6. Interestingly, the Current ETR and the Total ETR wer significant and had negative coefficients in the user variable, which shows that the derivative user companies are not the most tax aggressive ones, differing from the international literature. Therefore, it is seen here that less aggressive companies tend to use derivatives more than more aggressive companies do.

When the BTD is used as an explanatory variable in the model, the companies were also separated in order to use the regression model with probit estimation. The interpretation logic, however, must be inverse. Notice that the companies with higher BTD are, in fact, the most tax aggressive ones. Thus, regarding the BTD proxy as response variable of the 1.250 observations, the $10 \%$ statistical relevance model ( $\mathrm{p}$-value $=0,0950)$, squared $\mathrm{R}(0,7428)$, the model has not brought statistical relevance since the confidence interval is higher than ten percent.

Consequently, the results evinced that the most tax aggressive companies are not those that used financial derivatives more often, but the opposite. In other words, the less aggressive companies tend to use financial derivatives with higher propensity in the domestic market, which, in turn, indicates that the predominant use is for protection, rather than speculation, in the derivative market.

Nevertheless, in order to seek new empirical evidence in the Brazilian market in the ten years sampled (i.e., 2005 to 2015), the $25 \%$ of the most aggressive companies versus the $25 \%$ least aggressive ones were tested as shown in Table 7. In other words, the companies that would be in the $1^{\text {st. }}$ quartile were separated from the others in the $4^{\text {th. }}$ quartile, with the sole purpose of testing the result reached previously.

Aiming to facilitate the interpretation, in Table 7, the regression was run with the following premise: the " 1,00 " dummy ( $4^{\text {th. }}$ quartile) was used for the $25 \%$ least aggressive ones comparing them to the $25 \%$ most aggressive ones, for which the " 0,00 " dummy ( $1^{\text {st. }}$ quartile) was assigned. It is important, for now, to clarify that the interpretation logic was the contrary to that adopted in the analysis shown in Table 6, in order to didactically facilitate the understanding of the result. 
Table 7: Top / Bottom ( $1^{\text {st. }}$ Quartile vs $4^{\text {th. }}$ Quartile)

\begin{tabular}{|l|c|c|c|c|c|c|}
\hline & \multicolumn{3}{|c|}{ CURRENT ETR } & \multicolumn{3}{c|}{ TOTAL ETR } \\
\hline PROBIT & Coefficient & Inclination & $\mathrm{Z}$ & Coefficient & Inclination & $\mathrm{Z}$ \\
\hline CONST & $-0,2743$ & & $-1,214$ & $-0,1600$ & & $-0,5712$ \\
USER & 0,5537 & 0,1655 & 3,777 & 0,4723 & 0,0892 & 2,704 \\
VARLEV & 0,0009 & 0,0003 & 0,3962 & 0,0077 & 0,0015 & 2,702 \\
VARROA & 0,0589 & 0,0188 & 5,211 & 0,0416 & 0,0085 & 3,768 \\
DUMMYNOL & 0,2902 & 0,0994 & 1,307 & 0,4755 & 0,1196 & 1,908 \\
DEPREC & 10,9433 & 3,5021 & 3,445 & 17,9589 & 3,6826 & 4,322 \\
BTM & $-0,0223$ & $-0,0071$ & $-1,168$ & 0,0780 & 0,0160 & 2,084 \\
\hline
\end{tabular}

It is seen that even comparing both ends of the sample, the dependent ETR Total variable demonstrates that the least aggressive entities are those which tend to use the financial derivatives more often. That is, the least aggressive ones are those whose ETR is higher than $34 \%$, so it is clear that the $47 \%$ ones are those companies which, in fact tend to use the financial derivatives with greater propensity in their corporate routine. It is seen that the $\mathrm{Z}$ score is positive and below $3(2,704)$, showing $99 \%$ confidence interval, necessary for the statistical relevance of the model.

As seen in Table 7, using the 490 observations, the regression with probit estimation in the dependent Current ETR, reflects what has already been studied in the Total ETR. It is worth recalling that the least aggressive companies are above $34 \%$, and that, in this regression, the least aggressive ones ( $1^{\text {st }}$ quartile) were compared to the most aggressive ones ( $4^{\text {th }}$ quartile). Therefore, it is seen that in the explained Current ETR variable, the 55\% user coefficient reflects the fact that the least aggressive companies, relatively speaking, are more inclined to use financial derivatives than the other companies.

Thus, we clearly countered the hypothesis initially proposed in this paper, which aimed to point empirical evidence of the influence of derivative user companies being more tax aggressive compared to the non-user ones. And, an opposite tendency was empirically presented, in which less aggressive companies make more use of the derivatives in corporate practices than the corporations which are considered more tax aggressive.

Therefore, the difference between the stock market in Brazil and the North American one is objectively noticed, as demonstrated by Donohoe (2015a), whether because most of the volume of the stocks traded in B3 belong to a few listed companies, or because the financial market in Brazil is behind the North American markets regarding liquidity, celerity and size, or due to the end of the prestige of the existing box effect in part of the American tax accounting reality, which is different from that adopted in Brazil.

It should be emphasized that, nowadays, the US market is the greatest promoter and, therefore, the greatest users of financial derivatives in the world, and that is, in fact, the main reason why the result empirically obtained in the U.S.A. is different from that pictured in the Brazilian market. It is common to the CFOs of North American companies to daily deal with strategies resulting from the derivatives, offered as a 
routine by managers of financial institutions in the United States. This wide range of options contributes to increasing and potentializing the effective use of derivatives by the entities in tax planning practices and strategies.

Notwithstanding this, despite the empirical evidence, an additional robust test must be carried out in order to analyze whether the derivative user companies with hedge purposes are more tax aggressive than the other ones. Notice that the hedge has accounting features, especially when dealing with hedge accounting, whose results may also bring other reflections on the market of financial derivatives.

With respect to the use of hedging, in special hedge accounting, a new regression with the addition of the independent hedge variable to the main model was carried out, and the result in this opportunity reflects similarly that which had been already been covered by international literature, for example Donohoe (2015a).

The dependent Total ETR, Current ETR and BTD, in a regression with continuous data, through the Ordinary Least Square (OLS) had statistical relevance in the regression, reason why it was adopted in this addi- tional study, since the specific use of hedge accounting can singly be used for tax planning.

Observe that, in Table 8, the hedge coefficient is negative in $12 \%$, with a $90 \%$ confidence interval, which shows that the most tax aggressive companies use hedge accounting. One must recall that the lower the ETR, the most aggressive the company is, therefore, that is the purpose of this interpretation that is line with international literature.

Since, in Table 8, the coefficient of the hedge variable is also negative in the Current ETR because the lower the value, the most tax aggressive the company will be. Thus, with $95 \%$ confidence interval, the most tax aggressive companies tend to use hedge accounting more than the least aggressive ones.

Finally, as seen in Table 8, regarding the BTD dependent variable, the interpretation must be the opposite to those used for ETR, since the higher the BTD, the more tax aggressive the company will be. Therefore, the coefficient of the hedge accounting variable becomes positive, with $90 \%$ confidence interval, such that the most aggressive companies, with therefore a higher BTD and positive coefficient in the hedge variable, are those which tend to use financial derivatives more in corporate routine.

Table 8. Hedge - Derivative Users with Hedge Accounting Purposes

\begin{tabular}{|l|cc|cc|cc|}
\hline & \multicolumn{2}{|c|}{ CURRENT ETR } & \multicolumn{2}{c|}{ TOTAL ETR } & \multicolumn{2}{c|}{ BTD } \\
\hline MQO & Coefficient & P-Value & Coefficient & P-value & \multicolumn{2}{c|}{ Coefficient } \\
\hline CONST & 0,2996 & $1,77 \mathrm{E}-06^{* * *}$ & 0,3456 & $4,94 \mathrm{E}-011^{* * *}$ & 0,0449 & $4,47 \mathrm{E}-11^{* * *}$ \\
HEDGE & $-0,1584$ & $0,0352^{* *}$ & $-0,1292$ & $0,0758^{*}$ & 0,0064 & $0,0978^{*}$ \\
VARLEV & $1,37687 \mathrm{e}-05$ & 0,1033 & $1,09110 \mathrm{e}-05$ & 0,1321 & $-1,25086 \mathrm{e}-07$ & 0,7449 \\
VARROA & $-0,0146$ & $0,0248^{* *}$ & $-0,0136$ & $0,0140^{* *}$ & 0,0274 & $1,07 \mathrm{E}-133^{* * *}$ \\
DUMMYNOL & 0,1700 & $0,0518^{*}$ & 0,1772 & $0,0246^{* *}$ & 0,0075 & 0,2279 \\
DEPREC & 0,4032 & 0,653 & $-0,9849$ & 0,2247 & $-0,2519$ & $3,43 \mathrm{E}-06^{* * *}$ \\
BTM & 0,0149 & $0,071^{*}$ & 0,0158 & $0,0089^{* * *}$ & $-0,0032$ & $0,0201^{* *}$ \\
\hline
\end{tabular}

Note: Significance level at $10 \%\left({ }^{*}\right)$, at $5 \%\left({ }^{* *}\right)$ and at $1 \%\left({ }^{* *}\right)$. The tests which were not significant had p-value higher than 0,1 (N.S). 


\section{Conclusions}

This paper investigated the associative relationship between tax aggressiveness and the use of financial derivatives. The studies carried out bring strong evidence that, in Brazil, there are peculiarities which differ from some or much of the international reality, according to the values pointed by the multivariate tests.

Thus, the distinct results seen in America were not reached, since in Brazil, the least aggressive companies tend to use the financial derivatives more, than the more tax aggressive corporations. For this conclusion, besides the main regression, another test with the ends of the sample, whether it is the first or fourth quartile, a kind of top vs. bottom (the 25\% most aggressive companies and the $25 \%$ least aggressive ones) was carried out. The result obtained, however, was not altered, confirming the previous result.

Nonetheless, a possible explanation for the result obtained is the fact that tax aggressiveness is umbilically associated with tax risk increase. In turn, the most aggressive companies in Brazil tend to avoid speculating in the financial market because they do not intend to potentialize the already existing tax risk.

That said, an additional robust test was carried out with the inclusion of the hedge independent binary variable to the main model proposed. The group of financial derivative user companies, which indicate in their explanatory notes the adoption of specifically hedge accounting, was used. The resulting multivariate regression conformed to the result presented by Donohoe (2015a) regarding the North American market, in which the most aggressive companies tend to use more derivatives. On the other hand, with the continuous metrics of tax aggressiveness, the regression showed that the tax aggressive companies tend to use more hedge accounting than the least aggressive ones in Brazil.

Thus, regarding the hedge accounting multivariate regression, the results follow the North American ones, as seen in Donohoe (2015a); this derives from the fact that the use of hedge accounting provides a kind of financial incentive to the company. As outlined above, it is seen that the framework of derivative as hedge accounting makes tax planning easier since in case of the loss recorded of the corporation with planning, it can be deducted from the Corporate Income Tax, as if it were an operating expense of the company.

By another range of analysis, the entity decision making on certain uses of financial derivatives are mostly unobservable, and the idea that is is also a challenging task remains among the scholars; whether it is to understand, or to implement the financial derivatives. As a result, the confidential nature of the effective tax returns of a corporation can jeopardize the collection of part of the data and the result of the research, as well as the fact that tax aggressiveness in Brazil is measured through punctual proxies to estimate the local financial database.

It is important to highlight that the measures of tax aggressiveness used in this paper refer to just the taxes of the corporation accounting profit, which in Brazil would be Income Tax and Social Contribution. Thus, it is a nodal point that the proxy measures adopted can restrict the projections of the conclusions, especially regarding the Brazilian reality, which reveals a complex and heavy tax load.

Finally, the following are suggested for future research: i) that themes related to the use of derivatives consider other tax aggressiveness proxies, calculated via the tax load of EVA; ii) that there is effective analysis separated by sectors, as well as types of derivatives used; iii) that 
there is the effective analysis of the real motivation for the uses of financial derivatives; and, iv) that there is the comparison of the accounting repercussion resulting from the difference of tax treatment in different places in the world.

\section{References}

Bartram, S. M., Brown, G. W., \& Fehele, F. R. (2009). International Evidence on Financial Derivatives Usage. Financial Management, (38), 185-206. https://doi. org/10.1111/j.1755-053X.2009.01033.x

Bifano, E. (2009). Da tributação das operaçôes de Hedge realizadas com contratos de swap. In R. Mosquera (Coord.), O Direito Tributário e o Mercado Financeiro $e$ de Capitais [Vol. 1] (pp. 125-145). São Paulo: Dialéctica.

Caldas, M. (2015) O Conceito de Planejamento Fiscal Agressivo: Novos Limites ao Planejamento Fiscal? Coimbra: Almedina.

Calijuri, M. (2009). Avaliação da gestão tributária a partir de uma perspectiva multidisciplinar (Tese de doutorado, Universidade de São Paulo, Faculdade de Economia, Administração e Contabilidade. São Paulo, Brasil).

Chen, L. H., Dhaliwal, D. S., \& Trombley, M. A. (November 2007). The Impact of Earnings Management and Tax Planning on the Information Content of Earnings. https://doi.org/10.2139/ssrn.1028808

Donohoe, M. (2015a). Financial Derivatives in Corporate Tax Avoidance: A Conceptual Perspective. The Journal of the American Taxation Association, 37(1), 37-68. https://doi.org/10.2308/atax-50907

Donohoe, M. (2015b). The Economic Effects of Financial Derivatives on Corporate Tax Avoidance. Journal of Accounting and Economics, 59(1), 01-24. https://doi. org/10.1016/j.jacceco.2014.11.001

Ferreira, F. R., Martinez, A. L., Costa, F. M., \& Passamani, R. (2012). Book-tax differences e gerenciamento de resultados no mercado de ações do Brasil. Revista de Administração de Empresas, 52(5), 488-501. https:// doi.org/10.1590/S0034-75902012000500002

Freitas, L. R. (2013). Comparação das funçôes de ligação logit e probit em regressáo binária considerando diferentes tamanhos amostrais (Dissertação defendida no Programa de Pós-Graduação, Universidade de Viçosa, Departamento de Estatística. Minas Gerais, Brasil).

Galdi, F. C., Lopes, A. B., \& Lima, I.S. (2011). Manual de contabilidade e tributação de instrumentos financeiros e derivativos: (IAS39, IAS32, IFRS7, CPC 14, minutas do CPC 38, 39 e 40, normas da CVM, do Bacen e da Receita Federal do Brasil). 2a. ed. São Paulo: Atlas.

Graham, J., Hanlon, M., Shevlin, T., \& Shroff, N. (2014). Incentives for Tax Planning and Avoidance: Evidence from the field. The Accounting Review, 89(3), 9911023. https://doi.org/10.2308/accr-50678

Hanlon, M., \& Heitzman, S. (December 2010). A Review of Tax Research. Journal of Accounting and Economics, 50(2-3). 127-178. https://doi.org/10.1016/j.jacceco.2010.09.002

Hazan, P. R. (2004). Planejamento tributário: lucro real X lucro presumido. (Monografia de Bacharel, Universidade Federal de Santa Catarina, Centro Socioeconômico. Florianópolis, Brasil).

Higgins, D., Omer, T., \& Phillips, J. (2015). The Influence of a Firm's Business Strategy on its Tax Aggressiveness. Contemporary Accounting Research, 32(2), 674-702. https://doi.org/10.1111/1911-3846.12087

International Accounting Standard Board. (2005). International Accounting Standards $N^{o} 39$ Financial Instruments: Measurement and Recognition. London: IASB.

Keyes, K. M. (2008). Federal Taxation of Financial Instruments and Transactions. Boston, MA: Warren, Gorham, \& Lamont Publishing.

Contabilidad y Negocios (15) 29, 2020 / ISSN 1992-1896 
Klassen, K. J., Lisowsky, P., \& Devan, M. (2016). The Role of Auditors, Non-Auditors, and Internal Tax Departments in Corporate Tax Aggressiveness. The Accounting Review, 91(1), 179-205. https://doi. org/10.2308/accr-51137

Lietz, G M. (2013). Tax Avoidance vs. Tax Aggressiveness: A Unifying Conceptual Framework. https://doi. org/10.2139/ssrn.2363828

Lisowsky, P. (2010). Seeking Shelter: Empirically Modeling Tax Shelters Using Financial Statement Information. The Accounting Review, 85(5), 1693-1720. https://doi. org/10.2308/accr.2010.85.5.1693

McGuire, S. T., Omer, T. C., \& Wang, D. (2012). Tax Avoidance: Does Tax-Specific Industry Expertise Make a Difference? The Accounting Review, 87(3), 975-1003. https://doi.org/10.2308/accr-10215

Martinez, A. L. (2017). Tax Aggressiveness: A Literature Survey. Revista de Educação e Pesquisa em Contabilidade, 11(2017), 106-124. https://doi.org/10.17524/ repec.v11i0.1724

Martinez, A. L., \& Martins, V. (2016). Alavancagem financeira e agressividade fiscal corporativa no Brasil. Revista de Contabilidade da UFBA, 10(3). https://doi. org/10.9771/rc-ufba.v10i3.18383

Martinez, A. L., \& Ramalho, G. C. (2014). Family Firms and Tax Aggressiveness in Brazil. International Business Research, 7(3), 129-136. https://doi.org/10.5539/ibr. v7n3p129

Martinez, A. L., \& Silva, J. (2017). Agressividade fiscal das empresas brasileiras com transaçóes entre partes relacionadas no exterior. In XI Congresso Anpcont. Belo Horizonte, Brasil.

Martinez, A. L., \& Silva, R. (2017). Agressividade fiscal e o custo do capital de terceiros no Brasil. Revista de Gestão, Finanças e Contabilidade, 7(1), 240-251. https:// doi.org/10.18028/2238-5320/rgfc.v7n1p240-251

Martinez, A. L., \& Silva, R. (2018). Restrição financeira e agressividade fiscal nas empresas brasileiras de capital aberto.
Advances in Scientific and Applied Accounting, 11(3), 448463. https://doi.org/10.14392/ASAA.2018110305

Mills, L., Erickson, M., Maydew, E. (1998). Investments in tax planning. Journal of the American Tax Association, 20(1), 1-20.

Moreira, A. M. (2004) Pis e Cofins - Incidência sobre operaçôes de Swap/Hedge e variaçôes cambiais. Revista Dialética de Direito Tributário, (111), 9-20.

Mosquera, R., \& Lopes, A.B. (2009). Da tributação das operaçôes de Hedge realizadas com contratos de swap. In R. Mosquera Quiroga (coord.), O direito tributário e o mercado financeiro e de capitais [Vol 01], pp.11-32. São Paulo: Dialéctica.

Raskolnikov, A. (2011). Taxation of Financial Products: Options for Fundamental Reform. Tax Notes, 133(12). Columbia Law and Economics Working Paper No. 415.

Receita Federal (31 de agosto de 2015). Instruçáo Normativa RFB No 1585 . Dispóe sobre o imposto sobre a renda incidente sobre os rendimentos e ganhos líquidos auferidos nos mercados financeiro e de capitais. República Federativa do Brasil. Brasília: Senado Federal. Retrieved from http:// normas.receita.fazenda.gov. br

Rezende, G. P., \& Nakao, S. H. (2012). Earnings Management and The Relationship with the Taxable Profit of Brazilian Publicity-Traded Companies. Revista Universo Contábil, 8(1), 06-21. https://doi.org/10.4270/ ruc. 2012101

Ryan, S. G. (2007). Financial Instruments \& Institutions: Accounting and Disclosure Rules (2nd ed.). Hoboken, NJ: John Wiley \& Sons, Inc.

Santos, J., \& Silva, M. (2017). Derivativos e renda fixa: Teoria e aplicaçóes ao mercado brasileiro. São Paulo: Atlas.

Shackelford, D. A., \& Shevlin, T. (2001). Empirical tax research in accounting. Journal of Accounting and Economics, 31(1-3), 321-387. https://doi.org/10.1016/ S0165-4101(01)00022-2 
Scholes, M., \& Wolfson, M. (1992) Taxes and Business Strategy: A planning approach. Englewood Cliffs, NJ: Prentice Hall.

Scholes, M., Wolfson, M., Erikson, M., Hanlon, M., Maydew, \& Shevlin, T. (2015). Taxes and Business Strategy: A Planning Approach (5th ed.). Boston: Pearson.

Slemrod, J. \& Yitzhaki, S. (2002). Tax avoidance, evasion, and administration. In A. J. Auerbach \& M. Feldstein (Eds.), Handbook of Public Economics, volume 3, chapter 22 (pp. 1423-1470). Elsevier.

Stulz, R. M. (2004). Should We Fear Derivatives? Journal of Economic Perspectives, 18(3), 173-192. https://doi. org/10.1257/0895330042162359

Utumi, A C. (2010). Hedge via Operaçôes de Swap: Tributação pelo Imposto de Renda. Revista Dialética de Direito Tributário, (172), 18-34.
Waegenare, A., Sansing, R., \& Wielhouver, J. (2015). Financial Accounting Effects of Tax Aggressiveness: Contracting and Measurement. Contemporary Accounting Research, 32(1), 223-242. https://doi. org/10.1111/1911-3846.12068

Yanchisin, H., \& Ricks, J. (2006). Hedge identification and timing traps for the unwary. Tax Adviser (March).

Zeng, T. (2014). Derivative financial instruments, tax aggressiveness and firm market value. Journal of Financial Economic Policy, 6(4), 376-390. https://doi. org/10.1108/JFEP-02-2014-0013

Fecha de recepción: 01 de Julio de 2019 Fecha de aceptación: 18 de febrero de 2020 Correspondencia: antoniolopomartinez@gmail.com reinoso@reinosoecanedo.com.br rafaelmantonio@gmail.com rogiene2000@yahoo.com.br 